\title{
Seasonal Variation in the consumption of biomass fuel in a rural community of arid Patagonia, Argentina
}

\author{
Daniela Morales ${ }^{1}$; Soledad Molares ${ }^{1} ;$ Ana Ladio² $^{\star}$
}

\begin{abstract}
The use of biomass as an energy resource is key to the subsistence and development of diverse rural populations throughout the world. Particularly, the study of seasonal variation in firewood consumption contributes knowledge that can be used in detailed community management of this resource. In a rural community of the Patagonian steppe, seasonal variation in domestic consumption of fuel plants was studied. Possible socioeconomic conditioning factors (i.e., size of family unit, infrastructure of dwellings, number of combustion appliances used) were analysed, and seasonal variation in the richness of plant species used was determined. Average biomass consumption was found to be $12000 \mathrm{~kg} / \mathrm{year} / \mathrm{home}$ and $1479 \mathrm{~kg} / \mathrm{year} / \mathrm{per}$ capita, with significantly higher values during winter ( $63 \mathrm{~kg} / \mathrm{day} / \mathrm{home})$, than in summer $(18.5 \mathrm{~kg} / \mathrm{day} / \mathrm{home})$. The richness of fuel species used varied significantly during the year, and in line with biomass estimates, the highest use consensus for species was recorded during winter and autumn, with exotic species predominating. The maximum difference in species was registered in autumn, due to an increase in the stockpiling of wood bought for winter, when the preference is for high caloric value and accessible commercial price. During the year the main species used were Salix spp. and Nothofagus antarctica (G. Forst.) Oerst. The differential needs as seen from a local perspective, and their use strategies, require an integrated, multifaceted proposal, such as the progressive incorporation of high efficiency stoves and the implementation of local wooded areas for firewood.
\end{abstract}

Keywords: Energy; Subsistence; Scarcity; Resilience; Supply Strategies.

\footnotetext{
${ }^{1}$ CIEMEP, CONICET, UNPSJB. Roca 780. Esquel (9200). Chubut. Argentina.

2 INIBIOMA, CONICET, UNCo, CRUB. Quintral 1250. SC de Bariloche (8400). Río Negro. Argentina.
}

* Corresponding author. $\mathrm{E}$ E-mail address: ahladio@gmail.com

\section{INTRODUCTION}

Firewood is the most ancient source of energy (Schobert 2002) and essential for numerous human populations, particularly for the poor and/or marginalised, and those inhabiting rural areas. Its popularity is probably due to its environmental availability, easy handling and combustion, and a lack of access to alternative energy sources (Kumar and Sharma 2009; Ektvedt 2011; Medeiros et al. 2011).

This resource is used for subsistence living, principally for domestic activities, and 
can also be commercialised directly or as charcoal, which constitutes an incomegenerating activity for many primary producers (Arnold and Bird 1999). Malyshev (2009) reported that approximately 2600 million people, that is, a third of the global population, use firewood, charcoal, agricultural waste and sub-products of animal origin to satisfy most of their daily fuel needs. These are basic elements used for cooking and heating, and also form an integral part of social, economic and cultural life (Arnold and Bird 1999).

The use of biomass as an energy resource has been widely studied in many regions of South America (Córdova-Aguilar 1992; Ramos and Albuquerque 2012; Cardoso et al. 2015; Schueftan et al. 2016), and its growing consumption has raised considerable concern in different sectors of society, particularly in areas where this resource is scarce (Morales et al. 2017b; Silva et al. 2018). In general, studies reveal greater collection in winter, although little work has been done on analysis of seasonal variation (Kaschula et al. 2005; Stampella et al. 2016).

The environmental and socioeconomic implications of firewood dependence in South America and other countries have been extensively pointed out (Démurger and Fornier 2011; Medeiros et al. 2011; Reyes et al. 2015). The most visible environmental consequences are related to the disturbance of plant communities and their associated fauna, soil erosion, desertification and contaminating emissions (Cereceda-Balic et al. 2012; Kebede et al. 2015; Specht et al. 2015). In addition, the association with some socioeconomic aspects has been highlighted, such as rapid demographic growth and urbanisation rates, and insufficient State investment in public services that provide other sources of energy (Cline-Cole et al. 1990). In particular, the relation between poverty levels and consumption of this biomass has been under discussion, taking into account the need for an integrated approach that considers thermal insulation in the homes, the cultural importance of fire and food, and the combustion appliances used, among other factors (Bahamondes 2003; Brouwer and Falcao 2004; Shackleton et al. 2007; Ektvedt 2011; Schueftan and González 2013).

Fuelwood consumption patterns have been estimated in various regions and countries, showing notable variations (FAOSTAT 2015). For example, studies carried out in rural Himalayan communities situated at different altitudes registered consumption values that varied between 1.63 and $2.52 \mathrm{~kg} /$ day/per capita (Kumar and Sharma 2009). In Peruvian communities consumption of between $2.2 \mathrm{~kg}$ and 5.3 kg/day/per capita (Córdova-Aguilar 1992) were documented. Research performed in rural populations of Nepal indicates that the demand for fuelwood may vary from 200 to 2000 kg/year/per capita (Metz 1994). Many authors suggest that the great variability in consumption rates is mainly associated with type of climate, season, availability of woody plants, culture and economy (Tabuti et al. 2003; Bhatt and Sachan 2004; Top et al. 2004).

One scenario to consider which involves notable consumption of biomass fuel is presented by rural communities of the Patagonian steppe, where firewood gathering is essential for their subsistence and development (Cardoso et al. 2015; Morales et al. 2017a). Nevertheless, continued extraction has had important repercussions for this arid environment, which is highly vulnerable and susceptible to degradation (Izquierdo et al. 2009), resulting in a decrease in the resource (Morales et al. 
2017b). This problem affects a large part of Patagonia, and has a direct impact on the lives of inhabitants, which is evidenced in the greater distances and time currently necessary for gathering fuel species. The species used are mainly native, of high caloric value and cultural importance (Cardoso et al. 2015), whose consumption is complemented with lower quality and/or purchased firewood (Arre et al. 2015). The increasing scarcity of fuelwood found in the natural environment, in combination with rising market prices, generates uncertainty in these rural populations, as previously observed in different parts of the world (Camacho 2011; Blancas et al. 2014).

Understanding the annual cycle of environmental resource use, and particularly fuel species, requires profound local ecological knowledge (Berkes et al. 2000). This is defined as the body of knowledge acquired throughout history, including practices and beliefs, which evolves by means of adaptive processes and is maintained by cultural transmission (Berkes et al. 2000; Berkes and Davidson-Hunt 2006). In a cold continental environment like extra-Andean Patagonia this also implies planning of resource gathering, so that it will not be hindered by extreme winter climatic conditions, and will take full advantage of all available woody elements (waste from the pruning of forestry windbreaks, driftwood, etc.) (Arre et al. 2015; Morales et al. 2017b), the use of exotic species, whether invasive or cultivated (Cardoso and Ladio 2011), and strategies to optimise combustion (a mixture of species for kindling and ember production, both green and dry material, etc.) (Cardoso et al. 2015; Morales et al. 2017a).

In the Patagonian region an increase has been recorded in the consumption of fuel species over time, which reflects changes in the subsistence strategies of populations who used to be nomadic and are now sedentary or of low mobility. In particular, these processes involve diversification of the woody species used, incorporation of foreign species acquired through exchange, and overexploitation of the higher quality combustible species (Andreoni and Capparelli 2012). Furthermore, the type of house construction has changed, as different materials have been incorporated. Instead of straw, reeds and the traditional adobe, which has notable insulation properties (Belmonte et al. 2007; Celentano et al. 2014), corrugated iron, cement and bricks are being used, with a completely different capacity for thermal insulation (Carabelli 2006). In addition, the size and composition of households has shown a strong correlation with fuelwood consumption (Brouwer and Falcao 2004; Ramírez and Taborda 2014).

In Argentine Patagonia, fuelwood gathering is carried out in combination with livestock activities, and together these modify the communal landscape, particularly the areas closest to dwellings, considered by the people to be highly valued supply sites (Morales et al. 2017a). However, up to the present time it is not known how the biomass consumption pattern varies between seasons. This is fundamental for the development of management strategies that consider these differential needs, seen from a local point of view, in order to decrease the socio-environmental vulnerability associated with energy requirements.

In a rural community of the Patagonian steppe of Chubut, Argentina, our goal was to develop an understanding of the annual firewood pattern from a qualitative and quantitative perspective: 1) To study seasonal variation in domestic consumption of fuel plants (kilogrammes consumed per home and per capita); 2) To analyse possible socio-economic factors related to the 
differential consumption of fuelwood throughout the annual cycle (i.e., size of family unit, infrastructure of dwellings, number and type of combustion appliances used); 3) To determine seasonal variation in the richness of combustible species consumed during the year.

Our general hypotheses are: 1) Domestic biomass consumption per home and per capita increase during winter due to climate severity 2) Households with larger families consume more firewood than smaller ones 3) Local dwelling infrastructure influences firewood use, biomass consumption being lower in houses made of adobe. 4) Number of combustion appliances affects firewood consumption. 5) Richness of fuel species consumed varies seasonally, increasing in winter due to higher caloric requirements. Finally, possible local solutions to the patterns found are given to improving this situation.

\section{MATERIALS AND METHODS}

\section{Study area}

This study was carried out in Costa del Lepá $\left(42^{\circ} 34^{\prime} S\right.$ and $\left.71^{\circ} 03^{\prime} \mathrm{W}\right)$, situated in the northwest of Chubut province, Argentina, at $760 \mathrm{~m}$ a.s.I. This rural settlement lies on the Patagonian plateau and in the Lepá river basin (Figure 1). The region is characterised by low precipitation, with annual averages that do not exceed $200 \mathrm{~mm}$, mainly concentrated during autumn and winter, with average temperatures of $17.5^{\circ} \mathrm{C}$ in summer and $2.6{ }^{\circ} \mathrm{C}$ in winter (Mereb 1990), and strong winds throughout the entire year. The vegetation is typical of shrubby steppe, composed mainly of Mulynum spinosum (Cav). Pers., Senecio filaginoides DC., Nassauvia axillaris (Lag. ex Lindl.) D. Don., Berberis microphylla G. Forst., Grindelia chiloensis (Corn.) Cabrera, Corynabutilum bicolor (Phil. Ex K. Schum) and Schinus johnstonii F.A. Barkley, and corresponds to the phytogeographic region of Central Patagonia, Province of Patagonia (Cabrera 1976).

\section{Study population}

Costa del Lepá is a Mapuche settlement on communal land, where approximately 84 families reside (ECPI 2007). Despite their ancestral roots, their native language Mapudungun or Mapuzungun (mapu=land and zungun=speak) is spoken only by a bilingual minority of the population (20\%), while the remainder speak only Spanish.

Most inhabitants are small livestock farmers (sheep and goats), complementing this activity with small-scale agriculture and the raising of hens and turkeys for family consumption (Morales et al. 2017a). A small proportion of the population work in commerce, construction or are State employees. With regard to formal education, approximately $93 \%$ of the individuals interviewed in Costa del Lepá had received primary education, but around 33\% had not completed this level.

The Costa del Lepá community lies approximately $60 \mathrm{~km}$ from the nearest city (Esquel), and is situated in a vulnerable environment with serious problems of soil erosion, water shortage, and a drastic reduction in some native plant species. Inhabitants' quality of life of is that of subsistence, provoking a notable increase in emigration to urban centres in search of alternatives in terms of work and education (Stella and Tozzini 2014). Inhabitants suffer critical shortages that impede satisfaction of their basic needs, such as limitations in the availability of water and electricity, inadequate attention in health centres and 


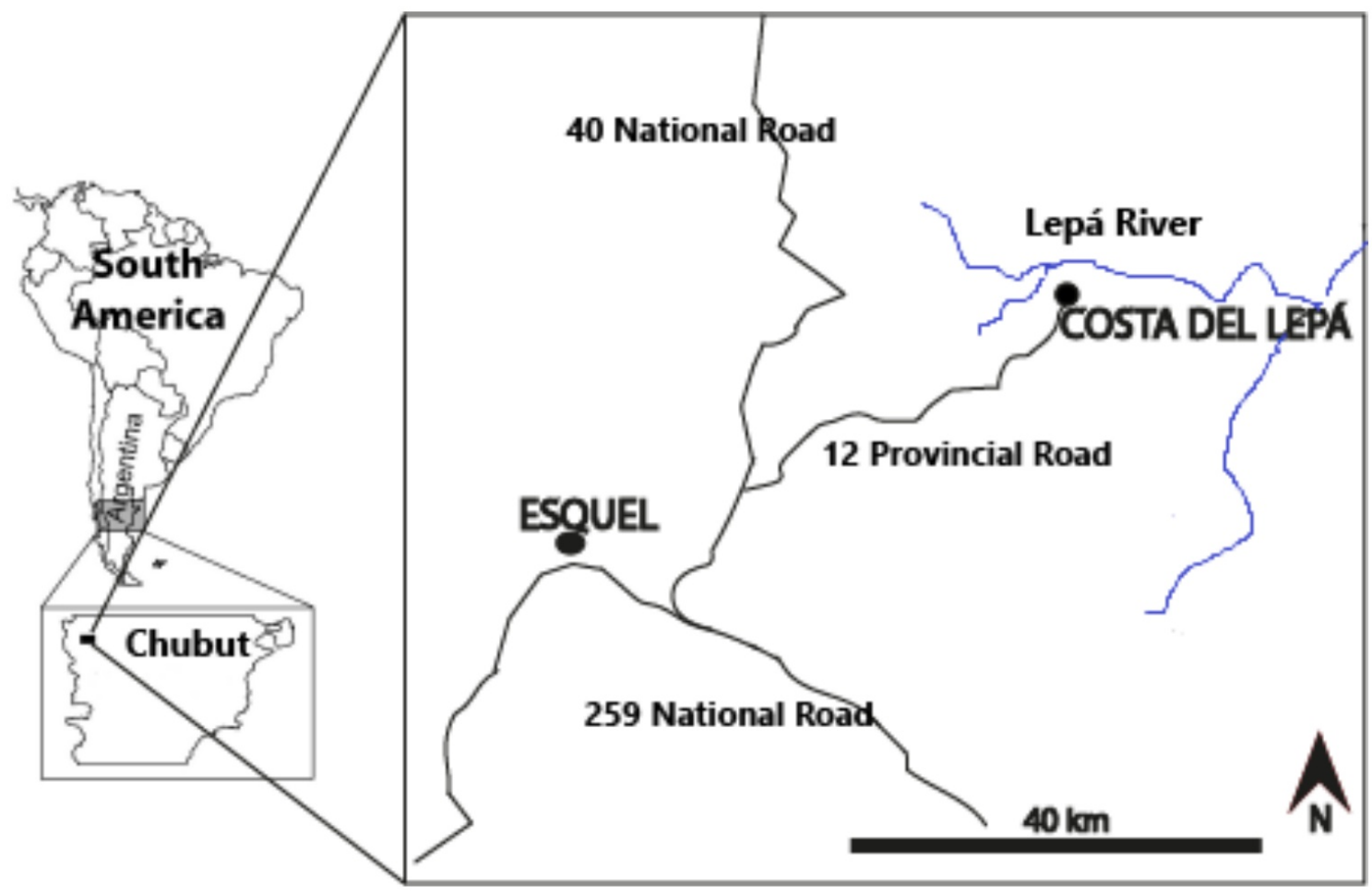

Figure 1. Location of the study area in NW Chubut province, Argentina. The blue line represents rivers in the settlement.

no access to gas or sewage networks, and they use the firewood resource as the main fuel for heating their homes and cooking their food.

\section{Data collection}

Using an ethnobotanical approach, 15 homes were visited in the Costa del Lepá community, belonging to families with whom we have maintained a close relationship of trust since 2011. Fieldwork was carried out according to the recommendations of prior informed consent established at the United Nations Conference on Sustainable Development (Rio+20 2012), for the regulation of access to genetic resources and the corresponding knowledge, protection of traditional knowledge and recognition of intellectual property rights. Furthermore, the guidelines of the Code of Ethics of the International Society of Ethnobiology (ISE 2006) were also followed. The homes analysed represented $18 \%$ of the total population, in part because of the complexity of the analysis required. One crucial outcome was identification of the participants who were willing to collaborate with us. The visits took place during all seasons of the annual cycle (between 45 and 60 days from the start of each season), beginning in summer 2016 and concluding in the summer of 2017; 13 trips were made in total. Participants were considered key informants (9 women and 6 men; average age $59+4.46$ years), as they were chosen 
because of their traditional ecological knowledge, in addition to their dependence on fuel species for heating (Albuquerque et al. 2014). First of all, we focused on an indepth analysis of each case, collecting detailed empirical information using participant observation over a sustained period of time. Due to this time-consuming procedure, our sample effort was limited but we gained insight into the rationality behind the patterns, in order to describe multiple realities rather than make generalizations.

In order to estimate the stock of biomass consumed $(\mathrm{kg})$ in each home/day/season, the amount of firewood (including kindling and ember-producing species) indicated by the key informant as the total amount used per day during the current season was weighed using portable scales, model Aspen BR9607. Following this, the different fuel species that made up the stock were identified taxonomically, whether obtained by gathering or other methods (e.g., purchase, exchange, State subsidies). In addition, participant observation and open and semi structured interviews were carried out to complement the information on firewood consumption and management in the homes, considering the types of stove, period of the day when the stoves were lit and for how long; alternative fuels, and characteristics of the dwellings in terms of their construction materials and thermal insulation, amongst others. Informants were also consulted on some socioeconomic aspects, such as size of the family unit, occupation and level of formal education.

\section{Data analysis}

Estimates of daily biomass consumption per capita (BCC) were based on the calculation $\mathrm{BCC}=\mathrm{BCH} / \mathrm{N}$, where $\mathrm{BCH}=$ daily biomass consumption per home and
$\mathrm{N}=$ number of members in the family unit (Kumar and Sharma 2009). Total annual biomass consumption was estimated using the calculation: $\Sigma A B C H^{*} d$, where $\mathrm{ABCH}=$ average daily biomass consumption per home for each season, and $d=n u m b e r$ of days of each season.

The data relating to daily biomass consumption per home and per capita for the 15 domestic units were analysed and compared between seasons (1. summer; 2 . autumn; 3. winter; 4. spring) using the Kruskal Wallis pairwise comparison test $(p<0.05)$.

Daily biomass consumption per home was compared between a) adobe and cement dwellings and b) those using only one appliance and those using more than one (range cooker, wood-burning stove, open fireplace) using the Mann Whitney test $(p<0.05)$. Size of family unit (number of members making up each family) was compared for the following categories: 1. one person; 2. two people; 3. three people; 4. four people, using the Kruskal Wallis test $(p<0.05)$.

Use consensus (UC) was estimated by considering the frequency of cites reporting the use of each species in relation to the total population, as an indirect measure of pressure of use. The number of informants (n) who used species (i) was divided by the total number of informants interviewed $(\mathrm{N}=15), \quad(\mathrm{UC}=\mathrm{ni} / \mathrm{N}) \quad$ (Molares and Ladio, 2012). This index was used as an indirect measure of the average pressure of use on the fuel species. For frequency of use, rankfrequency of use curves were used, employing the analysis criteria of rankabundance curves, in order to observe the richness and relative frequency of the fuel species in the different seasons of the year (Feinsinger, 2003; Cardoso et al. 2013). UC of the species was compared for the 
different seasons using the Kruskal Wallis test $(p<0.05)$, and biogeographic origin was compared using the Mann Whitney test $(p<0.05)$. Species richness was compared using the Kruskall Wallis test $(p<0.05)$. Similarity of species in the different seasons was estimated from the Jaccard index $(\mathrm{Jl}=\mathrm{Cl}$ $(a+b+c) \times 100 \%)$, where $c$ is the number of species two seasons have in common, $a$ is the number of species found only in season $A$, and $b$ is the number of species found only in season B (Höft et al. 1999).

The statistical analyses were performed with the InfoStat Statistical Package (Di Rienzo et al. 2010) and SPSS (Statistical Packpage for the Social Sciences) for Windows version 11.5. Information which is qualitative in character is presented in the form of testimonies, giving the initials and ages of informants. The fuel species were identified following Correa $(1971,1978$, 1984); their nomenclature and biogeographic origin were determined according to the Vascular Plant Catalogue of the Darwinion Institute (www.darwinion.gov.ar).

\section{RESULTS AND DISCUSSION}

\section{Seasonal variation in biomass consumption}

Consumption of firewood in Costa del Lepá homes varies greatly throughout the year (Figure 2A). During summer and spring consumption was very low with respect to winter, with average values of $18.45( \pm 3.58)$ $\mathrm{kg}$ per home and $19.33( \pm 3.45) \mathrm{kg}$ per home, respectively.

As expected, during the cold months (July, August and September), winter in the southern hemisphere, maximum values for biomass consumption were registered, at $62.89( \pm 10.39) \mathrm{kg}$ per home. Average daily consumption in autumn lay between these two extremes, at $36.13( \pm 2.91) \mathrm{kg}$ per home. Moreover, significant differences were found in biomass fuel consumption between the different seasons of the year (Figure 2A, Kruskal Wallis test, $p=0.0008$ ).

Similarly, average daily consumption per capita was lower in summer (11.27 $( \pm 3.03)$ $\mathrm{kg}$ per capita), and spring $(9.10( \pm 1.75) \mathrm{kg}$ per capita) in comparison with the winter period (32.94 $( \pm 7.5) \mathrm{Kg}$ per capita). Autumn values were intermediate, at $12.73( \pm 1.93)$ $\mathrm{kg}$ per capita. The differences in consumption per capita between seasons are significant (Figure 2B; Kruskal Wallis test, $p=0.0048$ ).

The daily per capita firewood consumption patterns in Costa del Lepá were found to be approximately three times greater during winter than in the spring and summer periods, which confirms our first hypothesis. These results are in accordance with the majority of fuelwood dependent communities of the world (Chettri et al. 2002; Bhatt, 2004).

Average annual biomass consumption in the Costa del Lepá homes surveyed was estimated at 12 tons/year/home and 1479 $\mathrm{kg} /$ year/per capita (Figure 2C). These values are similar to those recorded in rural communities of Zimbabwe, where the firewood consumption rate was 1300 kg/year/per capita (Marufu et al. 1999). Another study carried out in Patagonia estimated that in order to satisfy basic domestic needs approximately 10.5 tons/year/home (González et al. 2005) are required.

Our data contribute to highlighting the disparity of firewood consumption between different climatic regions of South America, and between countries around the world. Studies performed in tropical and subtropical zones of Peru revealed that annual biomass consumption per capita varied between 723 

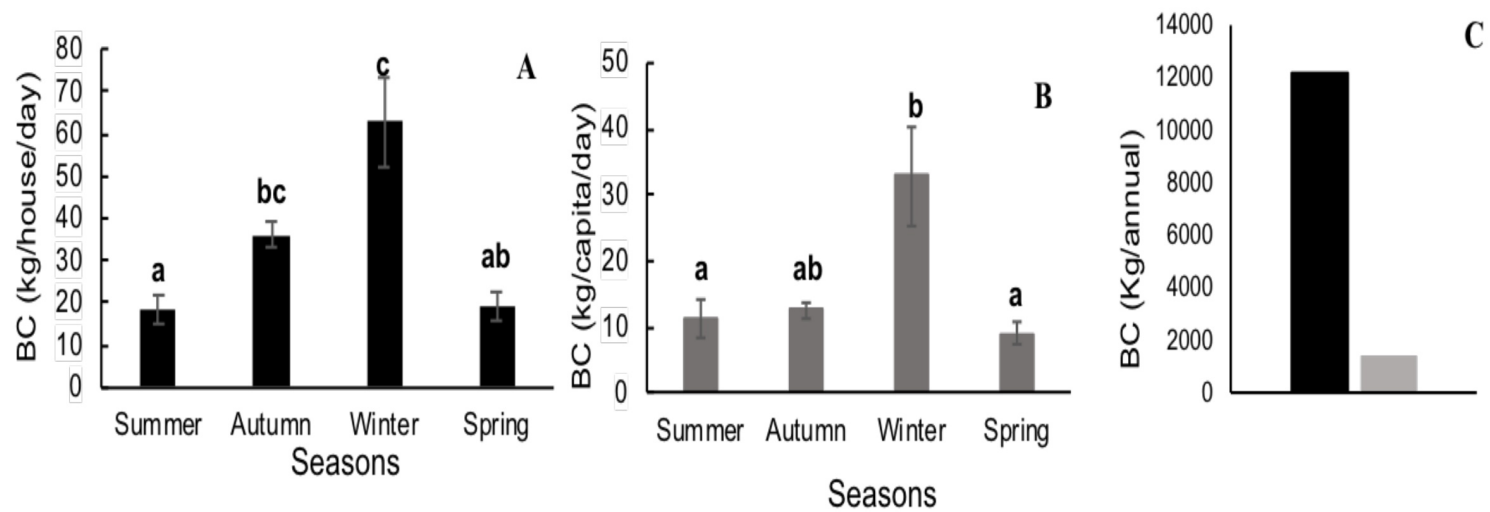

Figure 2. Biomass Consumption (BC) in Costa del Lepá, Patagonia Argentina. (A) Daily Biomass Consumption per home, according to season. (B) Daily Biomass Consumption per capita, according to season (C) Annual Biomass Consumption per home and per capita. Different letters indicate significant differences $(p<0.05)$. Key: $\square$ house; $\square$ capita.

and $1080 \mathrm{~kg} / \mathrm{year} / \mathrm{per}$ capita (Ektvedt 2011), or even between 839 and $1898 \mathrm{~kg} / \mathrm{year} / \mathrm{per}$ capita according to Córdova-Aguilar (1992). In rural regions of the Brazilian Atlantic, biomass consumption values varied between 686 and $961 \mathrm{~kg} /$ year/per capita (Specht et al. 2015), while in rural communities of Cambodia under similar climatic conditions values of $198 \mathrm{~kg} / \mathrm{year} / \mathrm{per}$ capita were obtained (Top et al. 2004). In semiarid environments of Africa biomass consumption of $538.8 \mathrm{~kg} /$ year/per capita (Madubansi and Shackleton 2006) was recorded.

In general, studies on the seasonal patterns of firewood consumption show variation between and within communities, which depends greatly on the level of vulnerability; that is, the inability to deal with change (Smit and Wandel 2006). In this community, whose environmental and socioeconomic context is vulnerable (i.e., increasing scarcity of a resource, they depend on, rural subsistence economy, no access to technological improvements), their consumption patterns are strongly linked to climatic and environmental variations.

\section{Time of day and duration of burning}

The lighting of fire and its duration varied according to the different purposes and seasons of the year. Most of the homes visited $(87 \%)$ reported that during autumn and winter the fire was lit almost all day, from morning till night-time. In contrast, in spring and summer the fire was lit only in the morning and at night to heat the home; gas cookers were used to a large extent, but only for the cooking of food $(90 \%$ of homes visited). Only occasionally, such as on days when the temperature was very low in spring and summer would the stoves be kept burning for most of the day. Some locals reported: "...when it's cold I have the stove on all day, my wife uses the range cooker a lot. First she puts in dry wood then she starts to put in green wood, so it goes further, and if it's not too cold I only light it in the morning and at night... in September the cold eases up..." (O.S., 55 years old); "...in spring I hardly put the fire on at all, I use the gas cooker more and maybe I only light the fire in the morning before I go to work, or at 
night, but very little, when it gets a bit colder..." (S.B., 45 years old). These reports reveal careful use of the resource, in accordance with the periods of greater climatic harshness, and also show how this resource is complemented with other fuel resources, demonstrating extremely measured use, and a firewood economy that is dedicated to saving.

\section{Biomass consumption in relation to socioeconomic variables Size of family unit}

Most family units that collaborated with this study (15 in total) were composed of two (five homes) or three (five homes) people, while the other homes were inhabited by four people (three homes) and one person (two homes).

In general, family units made up of three and four members showed the highest values of firewood consumption $(\mathrm{kg} / \mathrm{day} / \mathrm{home})$ for all seasons of the year, although these differences were not significant (Figure 3A; Kruskal Wallis test, $\mathrm{p}=0.457$ ). Ramírez and Taborda (2014) reported that more numerous family units presented higher firewood consumption than those with fewer members. In contrast, on analysing biomass consumption per capita in relation to size of family unit, lower values of firewood per capita were observed for family units with three-four members compared to families with one or two members, although the differences found were not significant (Figures 3B and 3C, Kruskal Wallis test, $p=0.267$ ) (Table 1). The more numerous family units generally save on firewood, as several members live together in the same home and use the same combustion appliances. For example, cooking collectively for several people tends to decrease the amount of firewood used per person, leading to more efficient use than in smaller family units. Similar results were documented by Kumar and Sharma (2009) and Bhatt et al. (2016).

In Patagonian homes it is also interesting to note the social value of keeping the fire lit, as a focus for various activities (e.g., "kitchen" conversations); this is an emblematic room for the reception of visitors or for the family to congregate in, constituting a valued space for both numerous families and people who live
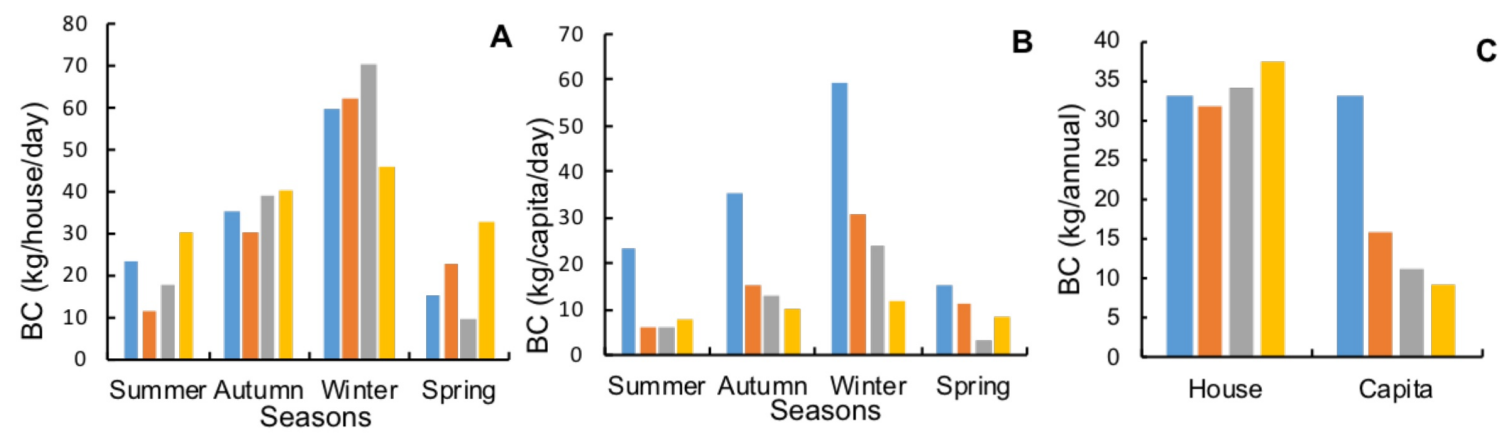

Figure 3. Biomass consumption $(B C)$ in relation to different sizes of family unit in Costa del Lepá, Argentina. A) Daily biomass consumption per home, for each season of the year. (B) Daily biomass consumption per capita, for each season of the year. (C) Annual biomass consumption per home and per capita. Key: Size of family unit: $\square$ one person; $\square$ two people; $\square$ three people; $\square$ four people. 
alone. This context could add another dimension to the results found.

\section{Infrastructure of dwelling}

In this study, it was observed that two main types of material were used in construction of the dwellings, $53 \%$ being made of adobe (mud and straw) and the remaining $47 \%$ of concrete.

Some authors (Belmonte et al. 2007; Celentano et al. 2014) state that adobe houses are generally more common in more disadvantaged rural populations. Natural elements in the surroundings are taken advantage of, and so are more economical, and the architecture of these houses also affords advantages in terms of acclimation of the house to sudden temperature changes (Lobera and Michelutti 2007). Nevertheless, although biomass consumption was slightly higher in the cement houses, no significant differences were found between the different construction types (Figure 4; Mann Whitney test, $p=0.28$ ). This could be explained by the fact that none of the adobe houses had adequate thermal insulation, and in general the doors and windows of these houses allowed air to pass freely to or from the exterior, and so they were greatly affected by

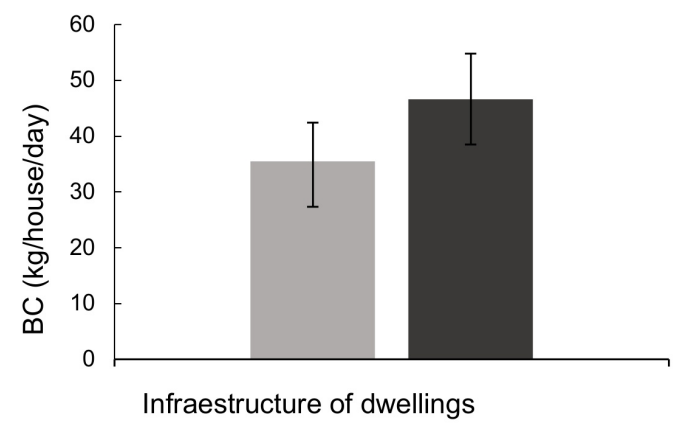

Figure 4. Differential biomass consumption (BC) according to the infrastructure of dwellings in Costa del Lepá, Patagonia, Argentina. Key: $\square$ adobe; $\square$ concrete. outdoor conditions. In contrast, the concrete houses were generally better maintained and cared for.

These results could also be affected by other factors, such as the age of the building. In general, the adobe houses were older and presented greater deterioration than the concrete ones, and so the structure was probably no longer efficient in terms of thermal insulation.

Type of combustion appliances used

\section{Type of stove}

In the Costa del Lepá community various types of stove are employed to meet heating and cooking needs. In $93 \%$ of homes a range cooker is used, which has been shown to present higher energy efficiency than other traditional cookers (AristizábalHernández 2010). The range is usually complemented with a gas cooker (liquid petroleum gas, or LPG) ( $80 \%$ of homes). To a lesser extent, complementary use of open fireplaces $(40 \%)$ and wood-burning stoves ("salamandras") (13\%) was recorded, and in only $7 \%$ of homes was the use of a modern low consumption firewood cooker registered.

The range cooker is therefore the principal stove used traditionally by inhabitants. In many homes the kitchen constitutes the main room, and is the preferred setting for family get-togethers. The permanent presence of a kettle of hot water on the range can frequently be observed, thus taking full advantage of the heat generated.

Coincidentally, in other regions of Argentine and Chilean Patagonia where locals have no access to the natural gas network, the range cooker is the appliance used most frequently by rural populations for cooking and heating (González et al. 2005; Díaz-Robles 2013). 
With regard to the number of appliances employed in each home that relies on firewood as fuel, eight homes were recorded as using only one, while seven homes used more than one type. Nevertheless, in both cases biomass consumption values were similar, corresponding to $43.3 \mathrm{~kg} /$ day/home in the homes using one stove, and 37.4 $\mathrm{kg} /$ day/home in those using more than one (Mann Whitney test, $p=0.53$ ). It is likely that more information and data are still required, particularly on cold days, to analyse this aspect. It is worthy of note, however, that the presence of two or more stoves does not imply their continuous, simultaneous use. This occurs occasionally, providing reassurance and a way of dealing with extreme climatic events.

In this study, the gas cooker (LPG) was used in a complementary way rather than a substitute energy source. This may be due to an inadequate distribution network and high costs. The restricted use of LPG coincides with other studies carried out in Latin America, and particularly in semi-arid environments (Ramos and Albuquerque 2012).

The gas cooker has some advantages for inhabitants in terms of saving wood, and shorter cooking time. However, some families did not consider this a satisfactory option, as food cooked in this way does not have the desired flavour, which they understand to be part of their customs, rooted in the values and traditions that constitute their identity. The inadequate adaptation of LPG stoves to cultural cooking practices also limits their use (Berrueta et al. 2008). For example, some of the traditionally prepared foods are roasted meat and wheat tortillas cooked in the embers of the fire. In both cases smoking and slow cooking are required. According to participants, these methods cannot be replaced by the use of
LPG or low consumption cookers.

In our study the evidence regarding the socioeconomic characteristics studied (i.e., family size, infrastructure of dwellings, number of domestic combustion appliances) and their influence on biomass consumption was not sufficient to affirm the hypotheses presented, since no significant variations were found. However, in the past some authors have highlighted the influence of these socioeconomic conditions on the pressure of use of firewood resources (Vermeulen et al. 2000; Démurger and Fornier 2011).

Also worthy of mention is the fact that during the period analysed, climatic conditions were not as severe as in other years, particularly during the winter (INTA 2018), so this could be an aspect to consider in evaluating firewood consumption. Future studies could further investigate this over a longer time period, which would include climatic variation between years.

\section{Richness of fuel species throughout the annual cycle}

A total richness of 15 fuel plants was registered in the Costa del Lepá community, of which the majority $(73 \%)$ were local native species, while species which are exotic to Patagonian represented $20 \%$ and $7 \%$ corresponded to a non-local native species from the Sub Antarctic forests of Patagonia.

Richness of the fuel species used varied throughout the annual cycle. In spring, summer and winter, the same richness of 12 fuel species was recorded, while in autumn the number of species used was only 4 (Kruskall Wallis test, $p=0.001$ ) (Figure 3). Exotic species belonging the genus Salix (willows) were the most used during the entire year, but particularly in autumn and winter. These species are obtained by 
gathering or purchase (Figure 5). During the warm months, and as a Nothofagus antarctica "ñire" (G. Forst.) complement in winter, locals also resort to Oerst, also stands out as being the most collection of native fuel plants, including both used species during the cold months, and kindling and ember-producing species, also during summer (Figure 5). This species among which $S$. johnstonii, $N$. axillaris, $B$. from the Sub Antarctic forest is highly microphylla, C. bicolor, Lycium sp., Stillingia appreciated by locals due to its high caloric patagonica (Speg.) Pax and K. Hoffm, value, and can only be obtained through Baccharis salicifolia (Ruiz and Pav.) Pers., purchase (Morales et al. 2017a). Populus Retanilla patagonica (Speg.) Tortosa, alba L. (white poplar) is also one of the most Ochetophilla trinervis (Gillies ex Hook. and frequently used exotic species in autumn Arn) and Chuquiraga avellanedae Lorentz and winter, and is obtained by gathering or and G. Forst., stand out (Figure 5).

purchase (Figure 5).
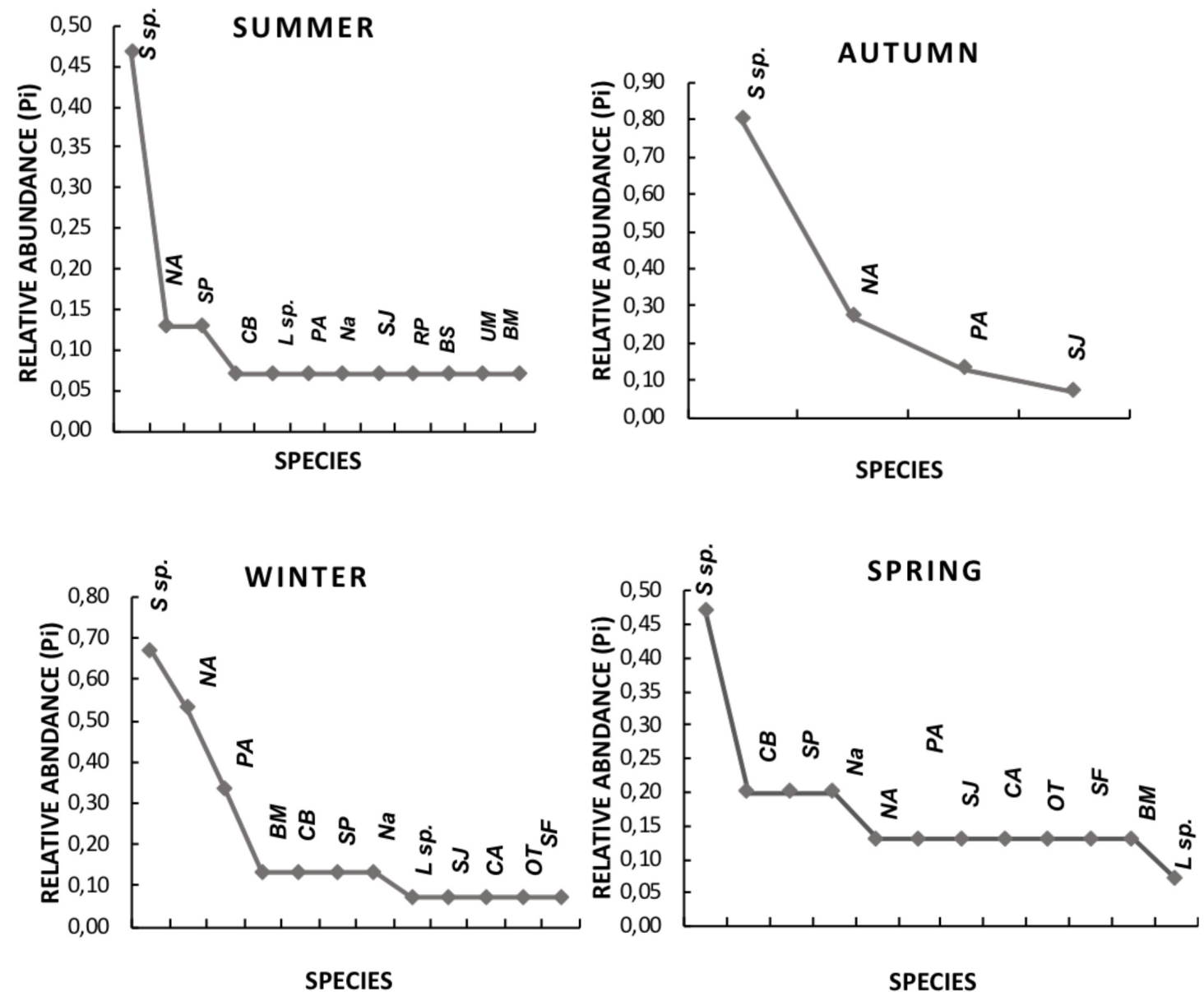

Figure 5. Curves showing frequency of use for fuel species in different seasons of the year in Costa de Lepá, Chubut. Key: Species: S sp. (Salix sp.); NA (Nothofagus antarctica); SP (Stillingia patagonica); CB (Corynabutilum bicolor); L sp. (Lycium sp.); PA (Populus alba) Na (Nassauvia axillaris); SJ (Schinus jhonstonii); RP (Retanilla patagonica); BS (Baccharis salicifolia); UM (UImus minor); BM (Berberis microphylla); CA (Chuquiraga avellanedae); OT (Ochetophila trinervis); SF (Senecio filaginoides). 
The average use consensus (UC) of fuel species used, an indirect method of measuring pressure of use, varied between the different seasons (Kruskal Wallis test, $\mathrm{p}=0.038$ ). During autumn and winter higher pressure of use was registered $(\mathrm{UC}=0.28$ and $U C=0.20$, respectively), than in spring $(U C=0.17)$ and summer $(U C=0.11)$. In particular, higher use consensus was observed for exotic than native species throughout the year, although the differences were significant only during winter (Mann Whitney test, $p=0.03$ ).

Regarding the similarity of species used in different seasons, we found the maximum value (100\% of species) between winter and spring, whereas only $60 \%$ of species were shared between summer and winter, and between summer and spring (Figure 3). Autumn showed the greatest difference in species composition in relation to the other months (33.3\% summer and autumn; 36.3\% autumn and winter; $36.3 \%$ autumn and spring) (Figure 3).

During autumn the richness registered was only 4 species, probably because in this season locals concentrate their efforts on stockpiling purchased firewood, and this stock, although lower in species richness (principally Salix spp., $N$. antarctica and $P$. alba), showed greater pressure of use on the resource compared to the other seasons, so as to build up an adequate stock of species with high caloric value for the cold months. In this season waste from the pruning of Salix spp. and $P$. alba was also taken advantage of, and this could be the optimum practice for this time of year, to the detriment of the gathering of other species. These resources normally satisfy the people's needs during this period, but do not last till winter, when locals again resort to purchasing their firewood.

In relation to caloric value, although the exotic species of the genus Salix presented lower values than $S$. johnstonii "molle" and N. antarctica (Caruso 2013; Cardoso et al. 2015), they were consumed to a greater extent, probably because of advantages in their acquisition, as they are relatively easily available (close to rivers and other water bodies, close to dwellings), and also circulate regularly on the commercial market (Arre et al. 2015). S. johnstonii is a species of high caloric value and is greatly appreciated by locals, but is currently very limited in availability (Cardoso et al. 2015; Morales et al. 2017a). Similarly, N. antarctica has important advantages as a fuel (Caruso 2013); however, due to its higher cost in relation to Salix spp., (approximately 23.6 USD/m3 for "ñire" and 12.7 USD/m3 for willow), many locals restrict its use.

In relation to our hypothesis, then, seasonal variation in the richness of fuel species and their pressure of use throughout the year in Costa de Lepá appears to be related to multiple factors, including not only needs in terms of calories, but also firewood supply sources and strategies.

\section{The market as a firewood supply source}

According to the informants in our study, local woody resources cannot satisfy their caloric requirements, and so they are obliged to buy firewood (Salix sp., P. alba, N. antarctica). For inhabitants of this community, situated no less than $60 \mathrm{~km}$ from the nearest city, this is still a cheaper alternative than using other energy sources, such as bottled gas or electricity.

Informants seem to indicate that a possible process of change may be taking place in the community as regards biomass supply sources (Morales et al. 2017a). Historically, past generations would rely 
mainly on firewood gathering, which would represent a higher demand in terms of time taken to procure the resource. However, at the present time, market dependence, reduced availability of native plants, and factors relating to community development have led to other strategies. Some locals say that: "... the people look for a way to buy, today it is possible to bring wood from outside, or some people close to the community sell it." (S.O, 45 years).

In accordance with this, previous studies carried out in other rural communities report an increase in the proportion of families buying firewood, reflecting a common strategy in response to scarcity of the resource in the local environment (Madubansi and Shackleton 2007). Furthermore, in other rural sites in arid environments of Patagonia, increased access to external markets for the provision of firewood has also been observed (Cardoso et al. 2017).

The greater dependence on purchased firewood seen in other regions and the use of exotic plants are strategies that result in lower pressure on local vegetation, and have been interpreted as part of a socioenvironmental resilience process on a local scale (Cardoso et al. 2017). However, this is somewhat controversial, given that inhabitants depend more on the availability of money to buy the firewood, and their biomass consumption is therefore being subsidised by other Patagonian ecological environments.

\section{Local solutions to the problem of firewood scarcity.}

Many studies have highlighted similar problems and the implementation of comprehensive local policies is being promoted, which will improve the wellbeing of these populations (Madubansi and Shackleton 2006; Guta 2014; Steelle et al. 2015). Recently proposed has been the implementation of local woodlots in order to favour self-sufficiency in fuel (Izquierdo et al. 2009; Morales et al. 2017b). These plans propose the cultivation of species of high cultural value, including native species with little local availability (i.e., S. johnstonii), and rapid growing, exotic species with a high resprouting capacity (i.e., Salix sp.; $P$. alba; $U$. minor). This proposal suggests taking gradual advantage of the resource, and emphasizes the contribution to environment restoration (Yao and Bae 2008; May, 2013), promoting species diversification and considering the control of potential invasions that may be caused by some of these exotic species, such as Salix sp. and $P$. alba (Fernández et al. 2014).

There is also growing interest in the propagation of species native to the Patagonian steppe, as a viable alternative for dealing with the problem of decreasing availability of the firewood resource (Izquierdo et al. 2009; Amico et al. 2017).

Furthermore, the incorporation of high efficiency stoves is another possible alternative. Previous studies have shown energy savings of around $65 \%$ in rural communities of Mexico which have incorporated this kind of stove (Berrueta et al. 2008). Berrueta et al. (2008) reported that a common phase in the transition from traditional low efficiency stoves to the improved ones is the simultaneous use of the alternative fuels present in the homes. Although it is still not known if this transition phase is related to locals trying to adapt their use of the stoves to local food preparation requirements or vice versa, a strategy for the production and promotion of stoves based on culturally specific cooking requirements (i.e., roast meat, ember-cooked tortillas in 
Patagonia) may serve to shorten this transition period. A stove improvement programme must therefore be considered from multiple perspectives, both in terms of energy efficiency and its acceptance on the part of local communities. In this way the improved stoves can contribute to improving the lives of rural inhabitants, and also decrease the use pressure on local woody flora.

\section{FINAL CONSIDERATIONS}

This approach enables us to understand, in a more comprehensive way, the socioeconomic and environmental context of rural populations, and how firewood use patterns change over time. Identification of the differential roles of the 12 most frequently used firewood species throughout the year can help in the development of management and conservation programmes of the firewood resource, as these species should be promoted in agroforestry projects in the region.

Our results highlight strong dependence on the regional biological resource, with the average biomass consumed being 12000 kg/year/home and $1479 \mathrm{~kg} / \mathrm{year} / \mathrm{per}$ capita. Although a more complete sampling process is required, and generalisations cannot be made, our results do reveal the current high pressure of use on this resource in the semiarid and ecotone regions (transitional zones between Forests and Steppe) in Argentine Patagonia. However, throughout the year, and particularly in autumn and winter, the most intense period of use, the role of exotic fuel species can be observed, acting as a buffer against this pressure of use. These results reveal the adaptive character of this strategy in biocultural terms, since some native species have a greater capacity for regeneration in the new, post- winter cycle if they have not suffered the pressure of winter thinning due to firewood collection.

Although it is necessary to investigate this subject in more depth, the present overview shows that family units all manage the firewood resource in similar ways, and that this does not vary according to the sociocultural factors analysed. Maintenance of common family traditions related to firewood use, and dependence on the availability of local wild plants, the purchase of firewood and cultivated resources appear to be the most important strategies that shape firewood use.

The implementation of comprehensive strategies such as those mentioned above could be plausible options, which clearly need an integral energy policy that contemplates local characteristics and requirements, given that these communities play the most active role in the management of this resource. This work constitutes an approach that combines culture with the use of the firewood resource in rural communities of arid environments. Further contributions are necessary, particularly in relation to biomass consumption estimates at species level, in order to strengthen comprehension and improve planning for the management and conservation of this resource in the context of the global climate change being experienced in the region.

\section{ACKNOWLEDGEMENTS}

We would like to thank the inhabitants of Costa del Lepá very specially, for their great help, kindness and willingness during this work. We are also grateful to the reviewer whose suggestions helped improve this work substantially. This study was financed by PICT 2012-1073, Agencia Nacional de Promoción Científica y Tecnológica (ANPCyT) and CONICET. 


\section{REFERENCIAS}

Albuquerque $U$ P, Ramos M A, Lucena R F P, Alencar N L (2014) Methods and techniques used to collect ethnobiological data. In Methods and techniques in Ethnobiology and Ethnoecology (pp. 15-37). Humana Press, New York, NY.

Amico I, Schinelli T, Bottaro H, Tejera L, Beloqui A, Bobadilla W, Ardenghi P (2017) Recuperación de bosque relicto de chacay en Gobernador Costa, Boletín de divulgación, 121-122. http://inta.gob.ar/esquel

Andreoni F, Capparelli A (2012) El ser humano y la leña en la cordillera de Mendoza (Argentina) a lo largo del Holoceno: sitio arqueológico Arrollo Malo 3. Magallania 40(1), 203-228. http://doi.org/10.4067/S071822442012000100012

Aristizábal Hernández J (2010) Estufas mejoradas y bancos de leña: una alternativa de autoabastecimiento energético a nivel de finca para comunidades dependientes de los bosques de roble en la Cordillera Oriental. Colombia Forestal, 13(2), 245-256.

Arnold J, Bird P (1999) Forests and the poverty-environment nexus. UNDP/EC Expert Workshop on Poverty and the Environment, Brussels, Belgium. http://doi.org/10.1080/00049158.1949.10675273

Arre J, Molares S, Ladio A, Kutschker A (2015) Etnobotánica de las plantas leñateras y su circuito comercial en una ciudad de la Patagonia Argentina. Gaia Scientia 9: 41-48.

Bahamondes M (2003) Poverty-environment patterns in a growing economy: Farming communities in Arid Central Chile, 1991-99. World Development, 31(11), 1947-1957. http://doi.org/10.1016/j.worlddev.2003.06.003

Belmonte S, Viramonte J, Núñez V, Franco J (2007) Situación actual y perspectivas de energías renovables en el Valle de Lerma Salta. Avances en Energías Renovables y Medio Ambiente, 11, 55-62.

Berrueta V M, Edwards R D, Masera O R (2008) Energy performance of wood-burning cookstoves in Michoacan, Mexico. Renewable Energy, 33(5), 859-870. http://doi.org/10.1016/j.renene.2007.04.016

Bhatt B (2004) Firewood consumption along an altitudinal gradient in mountain villages of India. Biomass and Bioenergy, 27(1), 69-75.
Bhatt B, Sachan M (2004). Firewood consumption pattern of different tribal communities in Northeast India. Energy Policy 32: $1-6$.

Bhatt B, Rathore S, Lemtur M, Sarkar B (2016) Fuelwood energy pattern and biomass resources in Eastern Himalaya. Renewable Energy, 94, 410-417. http://doi.org/10.1016/j.renene.2016.03.042

Blancas J, Casas A, Lira R, Caballero J (2009) Traditional Management and Morphological Patterns of Myrtillocactus schenckii (Cactaceae) in the Tehuachan Valley, Central Mexico. Economic Botany, 63(4), 375-387. http://doi.org/10.1007/s12231-009-9095-2

Berkes F, Colding J, Folke C. (2000). Rediscovery of traditional ecological knowledge as adaptive management. Ecol. Appl. 10, 1251-1262. http://doi: 10.1890/10510761(2000)010[1251:ROTEKA]2.0.CO;2

Berkes F, Davidson-Hunt I (2006). Biodiversity, traditional management systems, and cultural landscapes: examples from the boreal forest of Canada. Int. Social Sci. J. 58, 35-47. http://doi: 10.1111/j.1468-2451.2006.00605.x

Brouwer R, Falcão M (2004) Wood fuel consumption in Maputo, Mozambique. Biomass and Bioenergy, 27(3), 233-245. http://doi.org/10.1016/j.biombioe.2004.01.005

Cabrera A (1976) Regiones fitogeográficas argentinas. Enciclopedia Argentina de Agricultura y Jardinería, Tomo II Fs. 1st Edn. Buenos Aires: ACME. Bs. As. Argentina, 1-85.

Camacho L (2011) Conocimiento etnobotánico, patrones de uso y manejo de plantas útiles en la cuenca del río CaneIguaque (Boyacá - Colombia); una aproximación desde los Sistemas de Uso de la Biodiversidad. Ambiente and Sociedade, XIV(1): 45-75.

Carabelli F (2006) Proceso de planificación estratégica en el territorio de Gualjaina. https://www.researchgate.net/publication/263846 792

Cardoso M B, Ladio A (2011) Forestación peridoméstica en Patagonia y conocimiento ecológico tradicional: un estudio de caso. Sitient. Ciênc. Biol. 11, 321-327. doi: $10.13102 / \mathrm{scb} 110$ 
Cardoso M B, Ladio A H, Lozada M (2013) Fuelwood consumption patterns and resilience in two rural communities of the northwest Patagonian steppe, Argentina. Journal of arid environments, 98, 146-152.

Cardoso M B, Ladio A H, Dutrus S M, Lozada M (2015) Biomass and Bioenergy Preference and calorific value of fuelwood species in rural populations in northwestern Patagonia. Biomass and Bionergy , 81, 514-520. http://doi.org/10.1016/j.biombioe.2015.08.003

Cardoso M B, Lozada M, Ladio A (2017) Niche breadth and redundancy : Useful indices to analyse fuelwood use in rural communities. Journal of Arid Environments, 155, 52-59. http://doi.org/10.1016/j.jaridenv.2017.05.007

Caruso L (2013) Experimentación y propiedades combustibles de especies del bosque andino patagónico aportación al estudio antracológico de sitios arqueológicos. Magallania, 41(2):145-158.

Celentano D, Rousseau G, Engel V, Façanha C, Oliveira E, Moura E (2014) Perceptions of environmental change and use of traditional knowledge to plan riparian forest restoration with relocated communities in Alcântara, Eastern Amazon. Journal of Ethnobiology and Ethnomedicine, 10(1),

http://doi.org/10.1186/1746-4269-10-11

Cereceda-Balic F, Fadic X, Llanos AL, Guevara JL, Vidal V, Díaz-Robles LA, et al. (2012) Obtaining PAHs concentration ratios and molecular markers for residential wood combustion: Temuco, a case study. J Air Waste Manage Assoc. 62:44-51.

Chettri N, Sharma E, Deb D, Sundriyal R (2002) Impact of firewood extraction on tree structure, regeneration and woody biomass productivity in a trekking corridor of the Sikkim Himalaya. Mountain Research and Development, 22, 150-158.

Cline-Cole R, Main H, Nichol J (1990) On fuelwood consumption, population dynamics and deforestation in Africa. World Development, 18(4), 513-527. http://doi.org/10.1016/0305-750X(90)90068-9

Córdova-Aguilar H (1992). Firewood use and the effect on the ecosystem: A case study of the Sierra of Piura, Northwestern Peru. GeoJournal 26, 297-309.
Correa M N (1971) Flora patagónica. Parte VII. Compositae. Buenos Aires: Colección Científica del INTA. Bs. As, 451.

Correa M N (1978) Flora Patagónica. Gramineae. Tomo 8 Parte 3. Buenos Aires: Colección Científica del INTA. Bs. As.

Correa M N (1984) Flora patagónica. Parte IVa. Dicotiledóneas Dialipétaleas (Salicaceaea Cruciferae). Buenos Aires: Colección Científica del INTA. Bs. As., 559.

Démurger S, Fournier M (2011) Poverty and firewood consumption : A case study of rural households in northern China. China Economic Review, 33, 1-33.

Di Rienzo J, Casanoves F, Balzarini M, Gonzalez L, Tablada M, Robledo C (2016) Grupo InfoStat FCA. Universidad Nacional de Córdoba Argentina. [http=//www.infostat.com.ar] Accessed June 2016.

Díaz- Robles (2013) Estudio de consumo y caracterización del uso de la leña en la ciudad de Osorno. Informe Universidad Católica de Temuco. 1-133.

ECPI (2007) Encuesta Complementaria de Pueblos Indígenas [http://www.indec.gob.ar/] Accessed December 2015.

Ektvedt T M (2011) Firewood consumption amongst poor inhabitants in a semiarid tropical forest: A case study from Piura, northern Peru. Norsk Geografisk Tidsskrift, 65(1), 28-41. http://doi.org/10.1080/00291951.2010.549951

FAOSTAT (2015) Organización de las naciones unidas para la alimentación y la agricultura (FAO), Dirección de estadística FAOSTAT. http://faostat.fao.org

Feinsinger P (2003) El diseño de estudio de campo para la conservación de la biodiversidad. Ed. FAN Santa Cruz de Bolivia. $244 p$.

Fernández O, Leguizamón E, Acciaresi H (2014). Malezas e invasoras de la Argentina: ecología y manejo. 1a ed. - Bahía Blanca: Editorial de la Universidad Nacional del Sur. Ediuns.

González A D, Gortari S, Crivelli E (2005) Uso racional de energía y conservación de bosques en la Patagonia andina. Avances en Energías Renovables y Medio Ambiente 9, 1-6. 
Guta D (2014) Effect of fuelwood scarcity and socio-economic factors on household biobased energy use and energy substitution in rural Ethiopia. Energy Policy, 75, 217-227. http://doi.org/10.1016/j.enpol.2014.09.017

Höft M, Barik SK, Lykke AM (1999) Quantitative ethnobotany. Applications of multivariate and statistical analyses in ethnobotany. People and Plant Working Paper. Division of Ecological Sciences, UNESCO, Paris, France.

INTA (2018) Instituto Nacional de Tecnología Agropecuario. Agrometeorologia Esquel. https://inta.gob.ar/documentos/datosmeteorologicos-de-gualjaina

ISE (2006) International Society of Ethnobiology Code of Ethics. Available online at: http://ethnobiology.net/code-of-ethics

Izquierdo F, Velazco V, Abdel N (2009) Montes leñeros y cortinas de reparo en la región sur de Río Negro. 1 ed. Boletín de divulgación INTA, Buenos Aires.

Kaschula S A, Twine W E, Scholes M C (2005) Coppice harvesting of fuelwood species on a South African common: Utilizing scientific and indigenous knowledge in Community Based Natural Resource Management. Human Ecology (Vol. 33). http://doi.org/10.1007/s10745005-4144-7

Kebede A, Chimdi A, Nair A S (2015) Effect of Firewood Energy Consumption of Households on Deforestation in Debis Watershed Ambo District, Oromia Regional State. Ethiopia, 33(7), 1154-1163. http://doi.org/10.5829/idosi.wasj.2015.33.07.1458 6

Kumar M, Sharma C M (2009) Fuelwood consumption pattern at different altitudes in rural areas of Garhwal Himalaya. Biomass and Bioenergy, 33(10), 1413-1418. http://doi.org/10.1016/j.biombioe.2009.06.003

Lobera J, Michelutti E (2007). Construcción sostenible y construcción de la sostenibilidad : una experiencia en comunidades rurales de EI Salvador. Revista Internacional de Sostenibilidad, Tecnología y Humanismo, 53-68.

Madubansi M, Shackleton C M (2006) Changing energy profiles and consumption patterns following electrification in five rural villages, South Africa. Energy Policy, 34(18), 4081-4092
Madubansi M, Shackleton C M (2007) Changes in fuelwood use and selection following electrification in the Bushbuckridge lowveld, South Africa. Journal of Environmental Management, 83(4), 416-426. http://doi.org/10.1016/j.jenvman.2006.03.014

Malyshev T (2009) Looking ahead: energy, climate change and pro poor responses. Foresight, 11(4), 33-50. http://doi.org/10.1108/14636680910982421

Marufu L, Ludwig J, Andreae MO, Lelieveld J, Helas G (1999) Spatial and temporal variation in domestic biofuels consumption rates and patterns in Zimbabwe: implications for atmospheric trace gas emission. Biomass and Bioenergy;16:311-32.

May T (2013) Plantas preferidas para leña en la zona de bosque seco de Pedro Santana y Bánica, República Dominicana. Aspectos etnobotánicos y de manejo sustentable. Ambiente y Desarrollo, 17(33), 71-85

Medeiros $P$ M, Almeida A L S, Silva T C, Albuquerque U P (2011). Pressure Indicators of Wood Resource Use in an Atlantic Forest Area, Northeastern Brazil. Environmental Management, 47(3), 410-424. http://doi.org/10.1007/s00267-011-9618-3.

Mereb M (1990) Caracterización climatológica de los valles superior y medio del río Chubut. Dirección general de estudios y proyectos. Hidrometeorológico principal. Provincia del Chubut: Ministerio de economía, obras y servicios públicos.

Metz J (1994) Forest product use at an upper elevation village in Nepal. Environ Manag, 18(3):371-90.

Molares S, Ladio A (2012) Mapuche perceptions of Andean Nothofagus forests and their medicinal plants: a case study from a rural community in Patagonia, Argentina. Biodivers. Conserv. 21, 1079-1093. doi: 10.1007/s10531-012-0241-2

Morales D, Molares S, Ladio A (2017)a Firewood Resource Management in Different Landscapes in NW Patagonia. Frontiers in Ecology and Evolution 5:111. doi: 10.3389/fevo.2017.00111

Morales D, Molares S, Ladio A (2017)b A biocultural approach to firewood scarcity in rural communities inhabiting arid environments in Patagonia (Argentina). Ethnobiology and Conservation 6(12): 1-17. doi:10.15451/ec2017-08-6.12-1-17 
Ramírez-Quirama J, Taborda Vergara A L (2014) Consumo de leña en fogones tradicionales en familias campesinas del oriente antioqueño. Producción Más Limpia, 9(1), 99-114. http://doi.org/10.22507/pml.v9n1a8

Ramos M A, Albuquerque U P (2012). The domestic use of firewood in rural communities of the Caatinga: How seasonality interferes with patterns of firewood collection. Biomass and Bioenergy, 39 , 147-158. http://doi.org/10.1016/j.biombioe.2012.01.003

Reyes R, Nelson H, Navarro F, Retes C (2015) The firewood dilemma: Human health in a broader context of well-being in Chile. Energy for Sustainable Development, 28, 75-87. http://doi.org/10.1016/j.esd.2015.07.005

Schobert H (2002) Energy and Society (An Introduction). NY Ed.672 pp. 27, 57-68. http://doi.org/10.1016/j.biombioe.2003.10.008

Schueftan A, González A D (2013). Reduction of firewood consumption by households in south-central Chile associated with energy efficiency programs. Energy Policy, 63, 823-832.

http://doi.org/10.1016/j.enpol.2013.08.097

Schueftan A, Sommerhoff J, González A D (2016) Firewood demand and energy policy in south-central Chile. Energy for Sustainable Development, 33, 26-35. http://doi.org/10.1016/j.esd.2016.04.004

Shackleton C M, Shackleton S E, Buiten E, Bird N (2007) The importance of dry woodlands and forests in rural livelihoods and poverty alleviation in South Africa. Forest Police, 9(5), 558-577.

http://doi.org/10.1016/j.forpol.2006.03.00

Silva A, Medeiros PM, Júnior W, Silva R (2018) Does Forest Scarcity Affect the Collection and Use of Firewood by Rural Communities? A Case Study in the Atlantic Forest of Northeastern Brazil. Economic Botany, 72(1), 71-80. http://doi.org/10.1007/s12231-018-9403-9

Smit B, Wandel J (2006). Adaptation, adaptive capacity and vulnerability. Global Environmental Change, 16(3), 282-292. http://doi:10.1016/j.gloenvcha.2006.03.008
Specht M J, Pinto S R, Albuqueque U P, Tabarelli $M$, Melo FPL (2015) Burning biodiversity: Fuelwood harvesting causes forest degradation in human-dominated tropical landscapes. Global Ecology and Conservation, 3 , 200-209.

http://doi.org/10.1016/j.gecco.2014.12.002

Stampella P C, Doumecq M, Vojkovic M, Laborda L (2016) Valoración del cambio ambiental según los "junqueros" y "leñateros" en el sector sur de la región Rioplatense (Argentina). Bonplandia 25(1): 17-31.

Steelle M Z, Shackleton C M, Uma Shaanker R, Ganeshaiah K N, Radloff S (2015) The influence of livelihood dependency, local ecological knowledge and market proximity on the ecological impacts of harvesting nontimber forest products. Forest Policy and Economics, 50, 285-291. http://doi.org/10.1016/j.forpol.2014.07.011

Stella V, Tozzini A (2014) Existimos, porque acá estamos. Memorias de pertenencias y movilidades históricas interpelando modelos $y$ detenciones comunitarios actuales en el noroeste de la Provincia de Chubut. XI Congreso Argentino de Antropología Social. Facultad de Humanidades y Artes - UNR Rosario, Argentina.

Tabuti J, Dhilliona S, Lyea K (2003) Firewood use in Bulamogi County, Uganda: species selection, gathering and consumption patterns. Biomass and Bioenergy. 25, 581-596. http://doi.org/:10.1016/S0961-9534(03)00052-7

Top N, Mizoue N, Kai S, Nakao T (2004) Variation in woodfuel consumption patterns in response to forest availability in Kampong Thom Province, Cambodia. Biomass and Bioenergy, 27(1): 57-68.

United Nations (2012) Report of the United Nations Conference on Sustainable Development Rio +20. Rio de Janeiro, Brazil.

Vermeulen S J, Campbell B M, Mangono J J (2000). Shifting patterns of fuel and wood use by households in rural Zimbabwe. Energy and Environment, 11(3), 233-254.

Yao C E, Bae K (2008) Firewood Plantation as an Alternative Source of Energy in the Philippines. Journal of Forest Science. 24(3), 171-174. 
Received: 12 July 2018

Accepted: 17 October 2018

Published: 30 October 2018 